\title{
IMPLEMENTASI BAGIAN WASIAT HARTA WARIS ANAK ANGKAT DALAM KAJIAN KOMPILASI HUKUM ISLAM (KHI)
}

\author{
Senen Senen, Abdullah Kelib \\ Magister Hukum Universitas Semarang
}

\begin{abstract}
ABSTRAK
Penelitian ini bertujuan untuk mengetahui implementasi bagian harta waris anak angkat dalam kajian kompilasi hukum Islam. Wasiat merupakan pemberian seseorang kepada orang lain, baik berupa benda, piutang, maupun manfaat untuk dimiliki oleh penerima wasiat sebagai pemberian yang berlaku setelah wafatnya orang yang berwasiat. Dalam hukum kewarisan yang bersumber dari Al-Qur'an, anak angkat tidak dapat saling mewarisi dengan orang tua angkatnya karena tidak ada perkara yang membolehkan tuk mewarisi. Keadaan ini memunculkan perbuatan hukum berupa wasiat wajibah yaitu suatu wasiat yang wajib untuk diberikan kepada anggota keluarga yang secara hukum tidak memperoleh hak mewarisi dari si pewaris. Perumusan masalah dalam penelitian ini adalah (1) Apakah orang tua yang tidak membuat wasiat kepada anak angkat tetap bisa mendapat bagaian dari harta warisan? (2) Kendalakendala apa yang timbul dalam praktek wasiat wajibah untuk anak angkat? Metode pendekatan yang digunakan dalam penelitian ini adalah metode pendekatan yuridis normatif. Akibat hukum adanya pengangkatan anak menurut Kompilasi Hukum Islam (KHI) adalah munculnya Panggilan, Perwalian, Hak waris, Mahram kawin. Dalam hal kewarisan, anak angkat dalam KHI adalah tidak melepas nasab dari orang tua kandungnya, maka anak angkat tidak mewaris dari orang tua angkatnya dan sebaliknya, tetapi anak angkat mendapatkan wasiat wajibah yang tidak boleh lebih dari $1 / 3$ bagian dari orang tua angkatnya.
\end{abstract}

Kata Kunci : Wasiat wajibah; pengangkatan anak; kompilasi hukum islam 
e-ISSN : 2621-4105

\title{
IMPLEMENTATION OF PARTICIPATED CHILDREN'S HERITAGE TRAVEL IN THE ISLAMIC LAW COMPILATION STUDY (KHI)
}

\author{
Senen Senen, Abdullah Kelib \\ Master of Law, University of Semarang
}

\begin{abstract}
This study aims to determine the implementation of the portion of the inheritance of adopted children in a study of Islamic law compilation. A will is a gift to another person, either in the form of objects, receivables, or benefits to be possessed by the recipient as a gift which is valid after the death of the one who has a will. In the inheritance law sourced from the Qur'an, foster children can not inherit each other with their adoptive parents because there is no case that permits to inherit. This situation raises legal action in the form of a mandatory testament is a mandatory mandatory to be given to family members who are not legally entitled to inherit from the heir. The formulation of the problem in this study are (1) Are parents who do not make testament to adopted children can still get part of the inheritance? (2) What constraints arise in the practice of a must-have for adopted children? The method of the approach used in this study are normative juridical approach method. From the results of this research, it is known that (1) due to the existence of a legal adoption, according to a compilation of Islamic law (GENGHIS) is the emergence of call, Guardianship, inheritance, mating a Mahram. In terms of inheritance, the adopted child in GENGHIS ' is not forbidden to take off from his parents, then mewaris not adopted son from his adoptive parents and adopted children, but instead get a will wajibah which should not be more than 1/3 part of people adoptive parents.
\end{abstract}

Keywords: Will be mandatory; appointment of children; compilation of islamic law 


\section{A. PENDAHULUAN}

Hukum kewarisan Islam sudah menjelaskan secara rinci tentang tata cara pembagian dan peralihan harta warisan kepada ahli waris, harta warisan, serta halhal yang menghalangi ahli waris mendapatkan harta warisan dari si pewaris. Pembagian dan peralihan harta warisan kepada ahli waris antara lain dengan cara menyerahkan harta waris tersebut pada ahli waris yang berhak atau dan dengan wasiat apabila ahli waris seperti saudara atau kerabat yang terhalang mendapatkan harta warisan.

Wasiat merupakan pemberian seseorang kepada orang lain, baik berupa benda, piutang, maupun manfaat untuk dimiliki oleh penerima wasiat sebagai pemberian yang berlaku setelah wafatnya orang yang berwasiat. Menurut Kompilasi Hukum Islam, wasiat yaitu pemberian suatu benda dari pewaris kepada orang lain atau lembaga yang akan berlaku setelah pewaris meninggal dunia. Wasiat berlaku setelah seseorang wafat dan merupakan suatu kewajiban yang harus ditunaikan oleh ahli waris.

Dasar dari wasiat sendiri adalah surah al-Baqarah ayat 180:

"Diwajibkan atas kamu, apabila seorang di antara kamu kedatangan (tanda-tanda) maut, jika ia meninggalkan harta yang banyak, berwasiat untuk ibu-bapak dan karib kerabatnya secara ma'ruf, (ini adalah) kewajiban atas orang-orang yang bertakwa".

Wasiat yang pada dasarnya merupakan kemauan sendiri, namun dalam keadaan tertentu atau kasuistik, penguasa atau hakim sebagai pejabat negara; mempunyai wewenang untuk memaksa atau membuat keputusan wajib wasiat yang kemudian dikenal dengan wasiat wajibah kepada orang tertentu dalam keadaan tertentu disebabkan karena hilangnya unsur ikhtiar bagi pemberi wasiat dan munculnya unsur kewajiban melalui perundang-undangan atau surat keputusan tanpa tergantung kerelaan orang yang berwasiat dan persetujuan penerima wasiat, serta ada kemiripan dengan ketentuan pembagian harta waris dalam hal penerimaan laki-laki 2 (dua) kali lipat bagian perempuan.

Kompilasi Hukum Islam (KHI) di Indonesia wasiat wajibah diberikan bukan untuk cucu yang mahjub (terhalang) oleh anak laki-laki, tetapi wasiat 
wajibah diberikan kepada anak angkat. Hal ini sebagaimana ditulis dalam pasal 209 Kompilasi Hukum Islam. Menurut Hukum Islam, anak angkat tidak dapat diakui untuk bisa dijadikan dasar dan sebab mewarisi, karena prinsip pokok dalam kewarisan Islam adalah hubungan darah/nasab/keturunan. ${ }^{1}$

Pengangkatan anak tersebut merupakan alternatif untuk menyelamatkan sebuah perkawinan atau untuk mencapai kebahagiaan dalam rumah tangga, karena salah satu tujuan dari perkawinan yang dilakukan adalah untuk memperoleh keturunan yaitu anak. Begitu pentingnya hal keturunan (anak) ini, sehingga bisa menimbulkan berbagai peristiwa hukum jika tiada keturunan (anak) diantaranya terjadinya perceraian, poligami dan pengangkatan anak merupakan beberapa peristiwa hukum yang terjadi karena alasan didalam perkawinan tidak memperoleh keturunan, walaupun bukan satu-satunya sebagai alasan. ${ }^{2}$

Dengan kata lain bahwa peristiwa pegangkatan anak menurut hukum kawarisan Islam, tidak membawa pengaruh hukum terhadap status anak angkat, yakni bila bukan merupakan anak sendiri, tidak dapat mewarisi dari orang yang setelah mengangkat anak tersebut. Hal ini, tentunya akan menimbulkan masalah di kemudian hari apabila dalam hal warisan tersebut tidak dipahami oleh anak angkat, dikarenakan menurut hukum Islam, anak angkat tidak berhak mendapatkan pembagian harta warisan dari orang tua angkatnya, maka sebagai solusinya menurut Kompilasi Hukum Islam adalah dengan jalan pemberian "Wasiat Wajibah" sebanyak-banyaknya 1/3 (sepertiga) harta warisan orang tua angkatnya.

\section{B. PERMASALAHAN}

1. Apakah orang tua yang tidak membuat wasiat kepada anak angkat tetap bisa mendapat bagaian dari harta warisan?

2. Kendala-kendala apa yang timbul dalam praktek wasiat wajibah untuk anak angkat dan bagaimana solusinya?

\section{METODE PENELITIAN}

\footnotetext{
${ }^{1}$ Hilman Hadikusuma, Hukum Waris Adat, (Bandung: Citra Aditya Bakti,1990), hlm. 45

${ }^{2}$ Abidin Abidin, Abdullah Kelib, Rekonseptualisasi Akibat Hukum Pengangkatan Anak Menurut Kajian Kompilasi Hukum Islam, Jurnal USM Law Review Vol 1 No 1, Magister Hukum Universitas Semarang, 2018, Semarang, hal. 15.
} 
Metode yang digunakan dalam penulisan tesis ini adalah metode kualitatif dengan pendekatan yuridis normatif. Menurut Bogdan dan Taylor, metode kualitatif adalah prosedur penelitian yang menghasilkan data deskriptif berupa kata-kata tertulis atau lisan dari orang-orang dan perilaku yang dapat diamati. Pendekatan ini diarahkan pada latar dan individu secara utuh dan menyeluruh, serta tidak boleh terjadi diskriminasi terhadap individu tetapi harus dipandang sebagai satu kesatuan yang utuh. Sedangkan pendekatan normatif adalah untuk mengkaji penerapan kaidah-kaidah atau norma-norma dalam hukum positif. Penelitian ini disebut juga penelitian kepustakaan atau studi dokumen, karena penelitian ini lebih banyak akan dilakukan melalui studi kepustakaan atau lebih dikenal dengan studi pada data sekunder.

\section{PEMBAHASAN}

\section{Hak Anak Angkat yang Tidak Diberi Wasiat Oleh Orang Tua Terkait Harta Warisan}

Secara yuridis Islam, mengangkatan anak boleh saja dilakukan, tetapi mengangkat anak itu boleh (mubah) namun dengan syarat yang ketat seperti tidak mengubah status keturunan (nasab) dan tidak boleh menyamakan kedudukan hukumnya dengan anak kandung (nasabiyah). Hukum anak angkat dalam Islam adalah tidak sama statusnya dengan anak kandung.

Namun kesadaran beragama masyarakat muslim yang makin meningkat telah mendorong semangat untuk melakukan koreksi terhadap hal-hal yang bertentangan dengan syariat Islam, antara lain masalah pengangkatan anak. Dan hasil ikhtiar selama ini mulai tampak dengan lahirnya Kompilasi Hukum Islam sebagai pedoman hukum materil pengadilan agama mengakui eksistensi lembaga pengangkatan anak dengan mengatur anak angkat dalam rumusan pasal 171 huruf h. Bunyi isi pasal 171 huruf $h$ "anak angkat adalah anak yang dalam pemeliharaan untuk hidupnya sehari-hari, biaya pendidikan dan sebagainya beralih tanggung jawab dari orang tua asal kepada orang tua angkatnya berdasarkan putusan pengadilan.

Dengan demikian anak angakat dalam KHI adalah tidak melepas nasab seperti dalam pengertian hukum perdata. Pengertian anak angkat tersebut 
hanya sebatas pengambilalihan tanggung jawab kesejahteraan anak tersebut. Dalam hal ini tidak termasuk pemutusan nasab. Nasab anak angkat tersebut tetap pada orang tua kandungnya. Anak angkat tidak mewaris dari orang tua angkatnya dan sebaliknya. Anak angkat mendapatkan wasiat wajibah dari orang tua angkatnya dan sebaliknya sesuai dengan Pasal 209 KHI. Wasiat wajibah didapatkan berdasarkan putusan Pengadilan Agama. Pengertian wsiat wajibah adalah wasiat yang dianggap telah ada sebelum pewaris meninggal. Dan hanya bisa didapatkan berdasarkan putusan Pengadilan Agama. Besar bagian dari wasiat wajibah adalah tidak boleh lebih dari 1/3 bagian. Sedangkan wasiat biasa harus ada 2 orang saksi laki-laki yang telah memenuhi syarat untuk jadi saksi. Atau dalam bentuk tertulis yang disimpan oleh Notaris sebagai pejabat yang berwenang untuk itu dan harus dibacakan kepada ahli waris jika pewaris telah meninggal dunia. Wasiat ini dianggap tidak ada jika tidak ada saksi atau tidak tertulis. Pengangkatan anak menurut KHI ini adalah kewenangan absolut Pengadilan Agama, karena berkaitan dengan kaidah Hukum Islam.

Hal ini sesuai dengan tujuan hukum Islam, yaitu untuk merealisasikan kemaslahatan dan menghindarkan kemadharatan. Maslahat dapat dijadikan sumber penetapan hukum apabila:

a. Adanya kesesuaian antara maslahat yang dipandang sebagai sumber dalil yang berdiri sendiri dengan tujuan-tujuan syariah (maqosidu al-syariah)

b. Maslahat itu harus masuk akal, artinya bahwa maslahat mempunyai sifat yang sesuai dengan pemikiran yang rasional jika diajukan kepada kelompok rasionalis akan dapat diterima.

c. Penggunaan dalil maslahat ini adalah dalam rangka menghilangkan kesulitan yang terjadi, dalam pengertian bahwa apabila maslahat diterima oleh akal tidak diambil, niscaya manusia akan mengalami kesulitan.

\section{Kendala-Kendala Yang Timbul Dalam Praktek Wasiat Wajibah Untuk} Anak Angkat

Ketegasan hukum anak angkat dalam Islam atas dasar ayat al-Quran, berupa 'larangan' memberlakukan anak angkat seperti anak kandung dilihat 
dari sudut pandang teori kedaulatan Tuhan, dalam al-Quran dimuat beberapa ayat yang memerintahkan orang Islam untuk taat kepada Allah dan Rasul-Nya, tidak dibenarkan untuk mengambil pilihan lain kalau ternyata Allah dan RasulNya telah menetapkan hukum yang pasti dan jelas, mengambil pilihan hukum lain di mana Allah dan Rasul-Nya telah memberikan ketentuan hukum dianggap zhalim, kafir, atau fasiq, tanyakan pada hati nuranimu, apakah tidak termasuk umat Muhammad yang melecehkan al-Quran.

Penelitian ini berasusumsi dalam posisi inilah teori receptie a contrario dapat memberikan contoh bahwa hukum Adat telah diterima oleh hukum Islam. Tetapi, ketentuan wasiat wajibah bagi anak angkat 1/3 dari harta warisan pada awalnya banyak ditentang oleh ahli waris yang merasa dirugikan, yang mana hak mereka menjadi tergantikan dengan adanya pengakuan kedudukan anak angkat menjadi ahli waris pengganti. Padahal pengharaman segala tindakan yang dapat menimbulkan kerugian bagi ahli waris mutlak telah ditegaskan dalam sabda Rasulullah SAW yang berbunyi:

"Tidak boleh mendatangkan kemudharatan bagi ahli waris. Haram mewakafkan harta yang dapat menimbulkan kerugian bagi ahli waris, sebagaimana hadits Rasulullah SAW: tidak memudharatkan dan tidak dimudharatkan.

Selanjutnya, cara lain yang ditempuh untuk memberikan harta warisan kepada anak angkat adalah dengan cara adopsi. Adopsi ialah pengambilan anak laki-laki. Hukum adopsi berlaku di kalangan orang Cina, yang dimaksudkan suatu hak untuk mengambil seorang pemuda menjadi keturunan yang sah, disertai dengan pengakuan dari pihak yang mengambil untuk memperkenalkan nama sukunya (Sengnaam). Namun, masalah hak waris bagi anak adopsi dalam konteks hukum Islam di Indonesia telah diatur dalam Kompilasi Hukum Islam (KHI) sebagaimana pula ketentuan mengenai wasiat wajibah. Namun ada persoalan yang menarik untuk dicermati yaitu adanya yurisprudensi dalam Putusan Mahkamah Agung Nomor: 245 K/AG/1997 mengenai Hak Mewaris Anak Angkat. Ketentuan Pasal 209 KHI bahwa seorang anak angkat berhak maksimal $1 / 3$ bagian harta peninggalan orang tua angkatnya sebagai suatu 
wasiat wajibah. Surat kuasa khusus yang tidak memenuhi syarat yang ditentukan Undang-Undang karena cap jempol yang dibubuhkan pada surat kuasa oleh pemberi kuasa yang buta huruf tidak dilakukan di hadapan pejabat camat/notaris/hakim, maka surat kuasa yang demikian itu masih dapat diterima oleh hakim, karena pemberi kuasa tersebut telah ikut hadir dalam persidangan pengadilan agama, bersama dengan penerima kuasa.

\section{Solusi dari Kendala Pelaksanaan Wasiat Wajibah bagi Anak Angkat}

Sebagai solusi dari kendala tersebut diatas, dapat disimpulkan sebagai berikut:

1) Syari'at Islam tidak membenarkan memberi warisan kepada anak angkat, sebab anak angkat di dalam Islam tidak sama kedudukannya dengan anak kandung, oleh karenanya anak angkat tidak mendapatkan harta peninggalan orang tua angkatnya. Syari'at Islam melarang menghilangkan identitas anak angkat tersebut, anak itu harus dibangsakan kepada ayahnya. KHI cenderung memilih jalan yang kesesuaian, yakni anak angkat tidak termasuk ahli waris yang sama kedudukannya dengan anak kandung, hanya saja mereka dapat menerima wasiat dari orang tua angkatnya berdasarkan wasiat wajibah.

2) Berangkat dari ajaran Islam inilah agaknya KHI dirumuskan, dalam hal memberikan wasiat wajibah kepada anak angkat sebanyak-banyaknya sepertiga dari harta yang ditinggalkan oleh orang tua angkatnya apabila ayah angkatnya tidak berwasiat.

3) Motivasi dari Pasal 209 KHI ini tidak lain adalah berdasarkan atas rasa keadilan dan prikemanusiaan. Dirasa tidak layak dan tidak adil dan tidak manusiawi kalau hubungan timbal balik antara anak angkat dengan ayah angkatnya selama ini berjalan baik, tetapi setelah meninggalnya salah satu diantara keduanya hubungan ini dirasakan terputus, karena tidak sedikitpun harta yang didapatkan dari hubungan baik selama ini dan pada akhirnya hubungan ini membawa dampak yang buruk disebabkan adanya rasa sakit hati. Kecemasan-kecemasan inilah yang diantisipasi oleh pasal 209 KHI, 
sehingga kecemasan dan kekhawatiran serta kesedihan tersebut diharapkan tidak akan terjadi lagi.

4) Adanya ketentuan wasiat wajibah terhadap anak angkat di dalam KHI merupakan jembatan yang menutup ketimpangan yang terjadi selama ini antara anak angkat dengan orang tua angkat karena tidak saling mewarisi, karena tidak ada ketentuannya. Kondisi ini menyebabkan terjadi kekosongan hukum.

5) KHI untuk memasyarakatkan beberapa ketentuan hukum yang selama ini dianggap belum dapat diselesaikan yang terjadi di masyarakat. Keterikatan antara orang tua angkat dengan anak angkat merupakan keterikatan alamiah dalam kehidupan manusia, oleh sebab itu dengan cara menuangkan dalam aturan perundang-undangan (KHI).

6) Dengan demikian anak angakat dalam KHI adalah tidak melepas nasab seperti dalam pengertian hukum perdata. Pengertian anak angkat tersebut hanya sebatas pengambilalihan tanggung jawab kesejahteraan anak tersebut. Dalam hal ini tidak termasuk pemutusan nasab. Nasab anak angkat tersebut tetap pada orang tua kandungnya. Anak angkat tidak mewaris dari orang tua angkatnya dan sebaliknya. Anak angkat mendapatkan wasiat wajibah dari orang tua angkatnya dan sebaliknya sesuai dengan Pasal 209 KHI. Wasiat wajibah didapatkan berdasarkan putusan Pengadilan Agama. Pengertian wsiat wajibah adalah wasiat yang dianggap telah ada sebelum pewaris meninggal. Dan hanya bisa didapatkan berdasarkan putusan Pengadilan Agama. Besar bagian dari wasiat wajibah adalah tidak boleh lebih dari 1/3 bagian. Sedangkan wasiat biasa harus ada 2 orang saksi lakilaki yang telah memenuhi syarat untuk jadi saksi. Atau dalam bentuk tertulis yang disimpan oleh Notaris sebagai pejabat yang berwenang untuk itu dan harus dibacakan kepada ahli waris jika pewaris telah meninggal dunia. Wasiat ini dianggap tidak ada jika tidak ada saksi atau tidak tertulis. Pengangkatan anak menurut KHI ini adalah kewenangan absolut Pengadilan Agama, karena berkaitan dengan kaidah Hukum Islam. 
e-ISSN : 2621-4105

\section{E. PENUTUP}

Hukum adanya pengangkatan anak menurut Kompilasi Hukum Islam (KHI) adalah Akibat hukum yang ditimbulkan pengangkatan anak menurut Kompilasi Hukum adalah: a) Panggilan, Perwalian, Hak waris, Mahram kawin. Dalam hal kewarisan, anak angkat dalam KHI adalah tidak melepas nasab dari orang tua kandungnya, maka anak angkat tidak mewaris dari orang tua angkatnya dan sebaliknya, tetapi anak angkat mendapatkan wasiat wajibah yang tidak boleh lebih dari 1/3 bagian dari orang tua angkatnya sesuai dengan Pasal 209 ayat. Secara praktik, pemberian wasiat wajibah bagi anak angkat telah diputuskan oleh Lembaga Peradilan Agama sampai di tingkat kasasi di Mahkamah Agung seperti Pengadilan Tinggi Agama Nomor 63/Pdt.G/2009/PTA.Bdg, Putusan Mahkamah Agung Nomor 677/K/AG/2009.

Kendalanya adalah Yurisprudensi di Pengadilan Agama menunjukkan bahwa masih terdapat disparitas bagian wasiat wajibah bagi anak angkat. Sebagian hakim Pengadilan Agama tidak mau repot secara serta merta memberikan hak waris bagi anak angkat berdasarkan wasiat wajibah sebesar 1/3 dari harta warisan orang tua angkatnya, tanpa mempertimbangkan apakah pemberian maksimal tersebut telah merampas hak-hak ahli waris ataukah telah adil dan bijaksana. Sedangkan sebagian hakim lainnya memberi bagian wasiat wajibah tidak melebihi bagian terkecil dari ahli waris. Selain itu, dalam praktiknya anak angkat di Indonesia diperlakukan sebagai anak sendiri. Dan dengan dalih si anak banyak berjasa memelihara orang tua angkatnya, maka yang dipakai adalah fiksi hukum tersebut, kemudian diberi porsi wasiat wajibah dari harta warisan. Sebaliknya dalam putusan-putusan pengadilan negeri, anak angkat sama dengan anak sendiri, atas dasar hukum Adat sekalipun semua pihak beragama Islam. Solusinya adalah Anak angkat tidak mewaris dari orang tua angkatnya dan sebaliknya. Anak angkat mendapatkan wasiat wajibah dari orang tua angkatnya dan sebaliknya sesuai dengan Pasal 209 KHI. Wasiat wajibah didapatkan berdasarkan putusan Pengadilan Agama. 


\section{DAFTAR PUSTAKA}

\section{BUKU}

Al-Qur'an dan Terjemahnya, 2010, PT. Toha Putra, Semarang.

A. Hamid Sarong, 1997, Kompilasi Hukum Islam : Studi Pembaharuan Fiqh Indonesia, Peneliti DIP IAIN.

Ahmad bin Ali bin Hajar Al-Asqalani, tt., Fathul al-Bary, Jilid 12, Al-Maktabah Al-Salafiyah, Kairo.

Ahmad Kamil, et al., 2010, Hukum Perlindungan dan Pengangkatan Anak di Indonesia, cet. II, Rajawali Pers, Jakarta.

Ahmad Rofiq, 2000, Hukum Islam di Indonesia, cet. ke-4, Raja Grafindo Persada, Jakarta.

Departemen Agama Republik Indonesia, 2001, Himpunan Perundang-undangan dalam lingkungan pengadilan Agama, Dirbinbapera depag, Jakarta.

Departemen Agama RI, 2011, Al-Qur'an dan Terjemahannya, CV. Thoha Putra, Semarang.

Hilman Hadikusuma, Hukum Waris Adat, (Bandung: Citra Aditya Bakti,1990).

Peter Mahmud Marzuki, 2005, Penelitian Hkum Edisi Revisi, Kencana Prenada Media Group, Surabaya.

Zainuddin Ali, 2013, Metode Penelitian Hukum, Sinar Grafika, Jakarta.

Zakaria Ahmad Al-Bari, 1977. Ahkam al-Aulad fi al-Islam, Bulan Bintang, Jakarta.

\section{JURNAL}

Abidin Abidin, Abdullah Kelib, Rekonseptualisasi Akibat Hukum Pengangkatan Anak Menurut Kajian Kompilasi Hukum Islam, Jurnal USM Law Review Vol 1 No 1, Magister Hukum Universitas Semarang, 2018, Semarang

\section{UNDANG-UNDANG}

Kitab Undang-Undang Hukum Perdata

Kompilasi Hukum Islam

\section{Internet}

- www.badilag.net 